\title{
THE VARIETIES OF INTERTEXTUALITY IN ENGLISH-LANGUAGE ROLEPLAYING VIDEOGAMES ${ }^{* *}$
}

This paper aims at demonstrating various forms of intertextuality as exemplified by selective excerption of samples from a corpus of narrative and user-interface elements of roleplaying videogames, or RPGs. We review several types of excerpts, by applying various scientific methods (description, comparison, qualitative and quantitative analysis, induction). These excerpts include: the virtual "books" that facilitate the immersion into the RPG world, while adhering to the stylistic requirements of the respective real-world genres; unique fantasy idioms in dialog lines spoken by RPG characters, with references to English phraseology; and finally, the titles of missions that the player needs to complete, which are often based on allusions to English proverbs or classical literature.

Key words: intertext, popular culture, videogames, RPG, roleplaying games, phraseology, English language

\section{INTRODUCTION}

While one might argue that the concept of intertextuality dates as far back as discussion of self-sustaining Logos by Greek philosophers such as Heraclitus (Bondar', 2006), the true groundwork for studying the phenomenon was laid by the Bulgarian-French poststructuralist Julia Kristeva, who offered the very term "intertextuality" (Kristeva, 2000) to describe the way any given text generates new meaning by referencing other texts. While Kristeva was speaking specifically of literary texts, the term may also be applied to texts as semiotic systems created in other fields, much as modern digital media.

Researchers (see, for instance, Lapshina, 20011) believe that, by including references to other texts, the author establishes contact with a certain audience,

\footnotetext{
*ksuschannna@yandex.ru

** The paper was presented at ELALT 5 Conference
} 
which, as the author believes, is capable of recognizing and interpreting these references correctly. Intertextual insertions are also able to convey information about the sphere of knowledge where they were taken from, and to highlight the connections and similarities between several texts. Furthermore, intertextual insertions create additional, deeper layers of meaning, enriching the text where they occur. Specifically, they may serve as elements of wordplay - i.e. the creative, non-canonical use of language that allows the author to express their linguistic individuality, as well as draw the audience's attention (Konovalova, 2008).

This paper aims to expand the previous studies of intertextuality by demonstrating, through the methods of description, comparison, qualitative and quantitative analysis, and induction, how intertextuality manifests itself in a relatively unexplored medium: videogames. This type of entertainment, which may be defined as computer software that comprises digital graphics, audio, and text, has firmly established itself as an integral part of today's popular culture.

\section{A LINGUISTIC APPROACH TO VIDEOGAMES}

Since the emergence of videogames in the 1960s, the academic community's attitude towards them has been divided. Some early works by Russian critics, for instance, described videogames as "indubitable champions of violence" intended to "stir the aggressive fantasies of young people" (Shestakov, 1988: 4748). The first positive scholarly interpretation of videogames can be pinpointed to 2001, when a special conference on the subject of videogames was held in Copenhagen, Denmark, and the Swedish Research Council, together with the IT University of Copenhagen, began publishing the Game Studies journal, which aims to review videogames not only in terms of their technological aspect, but also in terms of their cultural and aesthetic significance. Since then, videogames have piqued the interest of researchers specializing in a diverse range of study areas, from information technology to psychology and education theory. However, linguistics has not yet accumulated a substantial research base on the subject of videogames.

One of the first scholars to study videogames from the linguistic point of view was the British researcher Astrid Ensslin. She has developed a classification of language used in videogames, as follows: language used by the gamers themselves for interacting during their videogame sessions, and discussing the games that they play; language used by videogame developers; language used by the media, politicians, activists, parents, teachers, and other outside parties as they discuss the sphere of gaming; language used within videogames, such as the user interface and 
various narrative elements that build the game's plot (e.g. dialog uttered by videogame characters) and finally, language used in various supplementary materials, for instance videogame walkthroughs (Ensslin, 2012: 6). Our study will focus largely on the narrative elements of videogames and, to a lesser extent, the interface, where intertextuality is present in the titles of game missions (quests).

The research corpus has been extracted from videogames belonging to the role-playing genre (RPGs), namely five fantasy RPGs - two from the Elder Scrolls series (developed by Bethesda Softworks and Zenimax Online), and three from the Dragon Age series (developed by BioWare and published by Electronic Arts) and three science fiction RPGs of the post-apocalyptic subgenre, from the Fallout series (developed by Bethesda Softworks). RPGs may be described as media where a person (the player) "through immersion into a role and the world of this role" such as a computer-generated quasi-Medieval or futuristic space-themed setting is given the opportunity "to participate in and interact with the contents of this world" (Hitchens, 2009). Such immersion is facilitated by vast amounts of textual material, which, as we have observed, often contains intertextual features.

\section{INTERTEXT IN VIDEOGAMES}

\section{Inserted Texts}

Firstly, the player may encounter intertext as it has been interpreted, among other researchers, by the distinguished Russian linguist Irina Arnol'd (1999), who views texts that have been created by the author "on behalf" of one of the characters as a form of intertext, since in this case, the entity that generates the text formally changes. One of the examples of this type of intertextuality cited by Arnol'd (ibid.) is the novel about Jesus (Yeshua) and Pilate, which has purportedly been written by the Master, one of the titular characters of Bulgakov's The Master and Margarita, and then gets interwoven into the framework of a different plotline, describing the chaos sown by the Devil and his entourage as they arrive in the pointedly atheistic Soviet Moscow, and the unholy company's encounter with the Master's lover Margarita. Thus, the Master's novel forms a text within a text, and may, from Arnol'd's point of view, be counted as an intertextual insertion (Arnol'd, 1999).

Insertions of this variety abound in videogames: as the player progresses through the plot, they may often encounter digitalized books, journal entries, notes, and other texts with authorship attributed to the game's characters. Sometimes studying these texts is obligatory for progressing further in the game: for instance, they may contain hints needed to solve a puzzle that the player has come across. On 
certain occasions, however, in-game texts serve no purpose other than adding more depth to the virtual world that the player is exploring, and exhibit features typical of real-world texts that belong to the same genre.

As a sample comparison of in-game texts and real-world texts, let us consider some textual material found in The Elder Scrolls V: Skyrim videogame. Among the books that the player can "read" while progressing through this fantasy RPG, is a three-volume scholarly treatise titled Dwarves, which is presented as a monograph on one of the game world's fictional cultures. It fully complies with the functional specifics of academic writing, and meets the requirements that would have existed for a similar text in real life. These include: the use of highly literary, "bookish" vocabulary (plethora of samples; discussion pertaining to dwarven machinery; in lieu of the more accurate term; [it] can be inferred from the writing), impersonal constructions (it would be erroneous to conclude), participial constructions (With that small point finished), a great variety of conjunctions that ensure proper cohesion between sentences and clauses (nevertheless), the so-called academic we (In our previous discussion, we looked into the properties of dwarven architecture and metallic crafts), and even the serial (Oxford or Harvard) comma, which is listed as one of the recommendations for academic writing in The Chicago Manual of Style ([we see the Dwarves as a] careful, intelligent, industrious, and highly advanced culture).

Similar features may also be found in other in-game texts that emulate academic writing. Looking at such texts in the Mass Effect series, where they are referred to as "codexes", we may point to the use of terminology for added authenticity: The second species to join the Citadel, the Salarians are warmblooded amphibians with a hyperactive metabolism; Turians come from an autocratic society; the Asari reproduce through a form of parthenogenesis...

The emulations of other fiction and non-fiction genres in RPGs also successfully implement the characteristic features of the real-world written works that they are meant to reflect. An interesting example would be a sonnet found in the Dragon Age: Inquisition videogame. It is presented as a poetic account of a sorcerer who wanted to conjure a perfect bride for himself from the spirit realm not unlike the sylphs found in real-world Romantic literature - but ended up transforming her into a cunning, cruel demonic creature.

When first I summoned her, she was a rose,

Unwithering, unchanging, and unthorned,

A spirit of the purest love one knows,

Who never hated, coveted, or scorned. 
A second time I drew her 'cross the Veil, And shared a walk, a dance, a stolen kiss; With such a perfect beauty, pure and pale, No woman could compare, no man resist.

Then in my weakness I essayed a third, Tho' magisters their warnings did impart.

She broke my binding with a single word, And said this smiling as she clutched my heart: "Though love I was, your passion's changing fire

Has forged this spirit into cruel Desire."

A qualitative examination of this work of poetry clearly shows that it complies with the stylistic requirements of the real-world literary canon on several language levels. On the phonetic level, we encounter such typical features as alliteration and assonance (unwithering, unchanging, and unthorned; perfect, pure and pale); on the lexical level, again, we may come across some "bookish" vocabulary (such as to essay instead of to attempt) and metaphors (she was a rose, your passion's changing fire); and on the syntactical level, we observe ellipsis (no woman could compare, no man resist) and inversion (when first I summoned her; though love I was).

In addition to merely emulating real-life texts, in-game texts may also parody them. As an example, let us review the magazines and comics found in the Fallout game series. The player cannot peruse their contents and can merely examine the covers, but even those are characterized by humorous references to various popular magazines with domestic advice. Since the actual subject matter of the magazines is survival in the harsh post-apocalyptic environment, the comical effect is created through contrasting positive and negative vocabulary: Farming The Wastes, The Bright Side of Radiation Poisoning, The Scrapyard Home Decoration Guide, Water Aerobics for Ghouls, etc.

\section{In-Game Idioms}

Another variety of intertextuality that makes RPGs more immersive is the creation of unique idioms, which transform the existing English-language expressions to fit the RPG world. Russian scholars (see, for instance, Kornilov, 2003) have extensively studied idioms as "building blocks" of the so-called linguistic worldview, i.e. the way various peoples perceive the world and reflect 
their perception through their respective languages. One may assume that the same is true of "artificial" idioms inserted into the speech of videogame characters. For the purposes of our study, we have collected over 280 such idioms. A qualitative analysis, as well as a comparative analysis of in-game idioms and their real-word counterparts has revealed that in-game idioms may be divided into several groups.

In the 280 -item idiom wordlist, 59 idioms, or roughly $20 \%$ of our material, are expressive, sometimes even profane exclamations invoking the names of various deities or other elements of the supernatural. In the real world, they would be comparable to God damn it! Go to hell! Jesus Christ on a bike!, etc. Some examples include: Y'ffre's bones! Maker's breath! By Stendarr's sweaty sword $a r m$ ! where Y'ffre, the Maker, Stendarr, and others are all names of fictional gods and spirits worshipped by the inhabitants of the respective RPG universes; or I will send you to Sovngarde!, Void take you!, where Sovngarde and the Void are terms for the afterlife.

The next group of idioms includes 57 expressions (or 19\% of the total amount of idioms that we have gathered) that contain the names of various fictional animals. Again, we may observe a parallel with real-world idioms, which often have animal names (zoonyms, in Russian research terminology) among their components, as a result of historically close interactions between humankind and the animal world.

Animal metaphors have always been an effective way of embodying difficult-to-grasp abstract concepts. More than that, studies show that one of the first human artistic creations that does not merely copy nature, but also includes an element of imagination and metaphorical thinking, was a depiction of a human-like lion, the so-called Löwenmensch, which is currently a museum exhibit in the German city of Ulm (Coolidge-Wynn, 2011).

Some of the animal metaphors included into RPGs are, in fact, the transformed versions of actual English-language idioms that contain the names of animals which are very much real. Let us compare, for instance, expressions such as to circle like vultures and to circle like cliffracers; or wild goose chase and wild guar chase. The components that are used to replace the original zoonyms, cliffracer and guar, are both names of fictional reptilian creatures inhabiting the RPG world of the Elder Scrolls series, which could be described as culturally significant for the fictional peoples that reside close to their habitat. We must note that these creatures share some characteristics in common with vultures and geese respectively: cliffracers are wild predators and, possibly, scavengers, whereas guar are grazers that can be tamed and raised as livestock. Moreover, the alliteration 
between the goose and guar components in our second example is also worth noting.

Apart from the animal world, real-world languages also source metaphors from the inanimate natural surroundings. Such metaphors also occur among idioms found in RPGs: 47 , or $16 \%$ of them contain components denoting weather phenomena, landscape features, and so forth. The idioms found in the speech patterns of characters belonging to the fictional Argonian race from the Elder Scrolls series - a nation of sentient, humanoid reptiles that has settled in humid marshlands - are particularly noteworthy. Upon analyzing these idioms, inductive reasoning has allowed us to conclude that they are based around what George Lakoff and Mark Johnson (Lakoff-Johnson, 2003) call a conceptual metaphor: a means of understanding one broad concept by describing it through vocabulary that pertains to another concept. Lakoff and Johnson list such examples of conceptual metaphors as ARGUMENT IS WAR, TIME IS A RESOURCE, etc.

In the case of the fictional Argonian race, the conceptual metaphor would be LIFE/FATE IS A RIVER, which reflects the marshy landscape that these fantasy beings live in. Idioms that are based on this conceptual metaphor include: Prying causes ripples in the river. I prefer my waters to remain still; The river has brought us here for a reason, etc.

Another notable group of metaphorical idiomatic expressions, both in real world and in RPG dialog, includes idioms with components denoting various artefacts, such as tools, pieces of furniture, or, in the case of the material we have gathered, food. Among all the idioms in RPGs, 49, or $17 \%$ of all our empiric data, contain references to fictional dishes, which, just as in the case of zoonyms, reflect actual idioms found in the English language. A good example would be such idioms as easy as blood berry pie and easy as scrib jelly pie, which are found in the Elder Scrolls games and are both based on the real English expression easy as pie.

The use of components denoting body parts is also a prominent feature of phraseology, and approximately $13 \%$ of RPG idioms that we discovered do contain references to the anatomy of fictional human-like beings. Quite a few of those belong to low colloquial speech and slang, which is in line with the findings of researchers studying slang in the real world, who point out that the human body, especially those parts of it that are considered improper to talk about in polite society, is a wellspring of new slang creation. Consider, for instance, the expression he is a bit of a cloaca, based on the slang phrase he is a bit of an asshole, and found in the dialog of a reptilian alien creature from the Mass Effect fictional universe, whose physiology differs from that of humans. 
Outside of slang, we should note idioms like I am yanking your tusk, which paraphrases the real-world expression I am pulling your leg, with the word tusk being a reference to the specific facial structure of the speaker, a character from the Elder Scrolls Online videogame, who belongs to the fictional Orc race, characterized by prominent boar-like tusks.

\section{Quest Titles}

Finally, we turn to consider intertextuality in the user interface of RPGs, where it is present as references inserted into the titles of missions the player needs to complete while advancing the plot.

These tasks are usually known as missions, or quests; the written description of a quest, which is logged into the player's in-game "journal", typically consists of a title and a brief overview of the objective that the player is to complete. While the objective is generally straightforward, giving the player a clear notion of what needs to be done, the quest's title quite often contains elements of wordplay that leverage the expressive potential of intertextuality. This may be explained by the fact that titles and headings perform a very specific cognitive function: according to Teun van Dijk, a heading creates a macrostructural representation of the text that is to follow it, preparing the audience for mentally processing the said text (van Dijk, 1988).

As a result, if the heading engages the audience by appealing to their background knowledge of the material that it is referencing, the likelihood of the recipient taking an interest in the text as a whole will increase, and the creator of the text will fulfill the goal of "urging" the potential recipient "into accepting the message" (Monsefi, 2016: 68). The linguistic and cognitive properties of intertextual insertions in headings have been widely studied in relation to the more traditional types of discourse, such as the language of mass media; this paper, in turn, aims to show that videogames also make use of intertext-based wordplay in a similar fashion.

In order to illustrate this point, we have managed to collect as many as 204 quest titles with intertextual insertions, sourced from the same set of games that we have outlined above. The vast majority of these quest titles (143 in all) contains references to English phraseology and set expressions. In a number of cases, the expressions that are being referenced undergo structural transformations, with one or more of their components being replaced with a lexical unit that either shares a morpheme with the component (pain in the neck -> Pain in the Necklace); rhymes with the component or is homonymous to it (lifting the veil -> Lifting the Vale; an axe to 
grind -> An Axe to Find) or contains an element with a similar phonetic structure (smooth jazz -> Smooth Jazbay, where jazbay is the name of the fictional wild grapes that the player has to gather). The component of an idiom or set expression may also be replaced with its antonym (falling asleep $\rightarrow>$ Falling Awake). However, the prevailing tendency within the group of 143 quest titles that we have singled out is for the idiom or set expression to retain its outer structure, while its semantics is being enriched as the quest's plotline references the literal meaning of one of its polysemantic components.

For example, in Elder Scrolls IV: Oblivion, the player may receive a quest titled A Brush with Death, which involves saving an artist whose use of an enchanted paint brush has led to him getting trapped within one of his own paintings; whereas in Dragon Age: Inquisition, a quest titled Seeing Red is dedicated to destroying ominous red crystals that have a negative effect on the mind of those who approach them - thus, the quest title is a play on the literal meaning of the adjective "red" and the figurative meaning of the idiom "to see red" (become angry and lose self-control).

It is also worth noting that in Fallout: New Vegas, a postapocalyptic videogame that takes places where the American states of Nevada, California, and Arizona were once located, a substantial share of the quests has titles that reference various set expressions from the conceptual sphere of gambling (Wild Card, The House Always Wins). This may be attributed to the association that exists between the state of Nevada and gambling in the minds of native English speakers, especially speakers of American English. In addition, we must point out that the latter of the quest titles cited, The House Always Wins, also serves as a play on the name of the character that gives the quest, $\mathrm{Mr}$. House.

The remaining 61 quest titles collected for the purposes of this paper contains references to a number of precedent texts and mass culture phenomena. When taking a closer look at this group of quest titles, we may see that some precedent texts serve as universal reference sources both for fantasy and science fiction RPGs, while others are referenced only within one of these two genres. Among the universal sources, we must first single out the Bible: references to this precedent text (13 in all) may be found in titles of quests both in fantasy RPGs (My Brother's Keeper, Sins of the Father) and science fiction RPGs (We Are Legion, Render Unto Caesar). It should be noted, however, that it is highly possible for today's native English speakers to have stopped recognizing certain intertextual insertions as references to the Bible, attributing them instead to other texts, as quotes from Biblical sources have been cited time and again throughout history by a large number of cultural and political figures. For instance, the quote If a house is divided against itself, that house cannot stand (Mark 3:25), which is referenced in the A House Divided quest in Fallout IV, made an appearance in one of 
Abraham Lincoln's most famed speeches, while the quote For now we see through a glass, darkly (I Corinthians 13:12), which is referenced in the Through a Nightmare, Darkly quest in Elder Scrolls IV: Oblivion, has been used as a title of multiple works of literature.

In the case of fantasy RPGs specifically, the most notable source of intertextual insertions is the writing of J.R.R. Tolkien, which is cited in such quest titles as Affairs of a Wizard, A Knife in the Dark, and others. In addition, quest titles may contain intertextual insertions from the works of William Shakespeare (Strange Bedfellows, What's in a Name, etc.), classical poetry (Promises to Keep), Arthurian legends (Spirit in the Lake), and fairytales. We believe that an example of an intertextual insertion from the latter source needs to be reviewed separately, as it presents an interesting case of appealing to the audience's background knowledge. The example in question is a quest from Dragon Age: Inquisition, titled Bring Me the Heart of Snow White.

The quest, which entails hunting down a fantasy creature that is white in colour and extracting its heart, is given to the player by a powerful female enchantress, who does not disclose what she needs the heart for. The association with the evil queen ordering her huntsman to destroy Snow White may prompt the player to assume that the enchantress also needs the white creature's heart for nefarious purposes. In the end, however, the audience discovers that the enchantress' intentions are benevolent (and the quarry itself, incidentally, is a dangerous mythical beast, far from the defenseless young girl that appears in the fairytale). This subversion of the widely-known plot disrupts the linear scenario that the player was preparing for, thus forcing them to engage their mental processes more actively, and making the quest more memorable.

It is also worth noting that the specific geographical location of Fallout: New Vegas, which we emphasized before, prompts an extensive use of intertextual insertions from the cowboy folklore and Western films (By a Campfire on the Trail, Wild Bill's Last Stand, They Went That-a-Way, Here Stands the Grass, and A Pair of Dead Desperados).

\section{CONCLUSION}

We have met our goal of demonstrating three main varieties of intertextuality in roleplaying videogames: inserted texts, which clearly have a correlation with realworld literature; specially coined idioms, which also have counterparts in English phraseology and slang across several classification groups (including idioms with names of body parts, animal name, etc.) and even allow to reconstruct a conceptual metaphor; and names of missions (quests), which aim to capture the audience's attention through references to widely known cultural phenomena. Our classification of 
intertextual insertions found in RPGs has also revealed how diverse such phenomena may be, ranging from the Bible and the works of William Shakespeare to cowboy songs.

Furthermore, we have showcased the various transformations that accompany the inclusion of intertextual references, both disrupting the linear narrative to alert the audience to the presence of intertextuality, and creating humorous roleplay. Such transformations are largely based on the systemic features of the English language, including the prevalence of homonymy and polysemy.

Our findings demonstrate that videogames, while being a rapidly developing contemporary type of entertainment, are closely interlinked with other products of human creativity, history, and culture. The existence of linguistic and cultural references, which presuppose the audience having a certain scope of background knowledge, may serve to disprove the claim that videogames dull the human intellect and promote the idea of mindless violence. The expressive use of language in videogames, especially those with a complex plot and an immersive virtual world, allows them to establish themselves as a valid subject of linguistic study.

Translating such intertextual elements of videogames from English into other languages may be a particularly promising area, as the cultural points of reference that are widely known to an English-speaking audience may be unfamiliar to videogame players from non-English-speaking countries.

Kseniia Bogdanova

\section{VARIJETETI INTERTEKSTUALNOSTI U VIDEO-IGRAMA SA IGRANJEM ULOGA NA ENGLESKOM JEZIKU}

\section{Rezime}

Cilj ovog rada je da prikaže tri tipa intertekstualnosti u savremenim video-igrama, koje definišemo kao tip softvera za zabavu sa elementima grafike, zvuka i pisanog teksta. Svrha studije je osvetljavanje načina na koje su video-igre sa igranjem uloga integrisane u popularnu kulturu, naročito kulturu zemalja engleskog govornog područja.

Sakupili smo tekstualne podatke, poput uzoraka korisničkog interfejsa i dijaloga likova, iz onlajn baza podataka posvećenih nekolikim video-igrama sa elementima fantazije i onima scifi karaktera sa igranjem uloga (koje su objavile istaknute američke i kanadske kompanije poput Electronic Arts i Bethesda Softworks) radi izdvajanja primera različitog intertekstualnog upućivanja na književnost pisanu na engleskom jeziku, popularnu kulturu i frazeologiju. Prvi tip takvog upućivanja, otkriven putem komparativne analize, jeste sličnost između virtuelnih knjiga koje igrač može „čitati“ dok igra video-igru sa igranjem uloga i „stvarnih“ objavljenih dela 
književne i neknjiževne proze. Na primer, Dwarves, monografija iz The Elder Scrolls V: Skyrim koja je uključena u igru da poduči igrača o fikcionalnoj trci patuljaka, prati uputstva akademskog pisanja, poput onih u the Chicago Manual of Style, na svakom nivou teksta, od vokabulara $\mathrm{i}$ sintakse do izgovora.

Naredni varijetet intertekstualnosti koji smo pronašli u video-igrama sa igranjem uloga je vrsta idioma koji transformišu postojeće izraze iz engleskog jezika kako bi odgovarali svetu ovih igara (npr. reč „goose“ u ,wild goose chase“ zamenjena je rečju „guar“, koja označava stvorenje iz fantazije). Klasifikujemo takve idiome, pronađene u replikama iz dijaloga u igrama, prema aspektu sveta koji reflektuju (npr. geografija, biologija, itd) i nalazimo da neke od najvećih grupa među njima čine: idiomi sa imenima božanstava i upućivanjem na natprirodno, idiomi sa imenima životinja, idiomi sa imenima prirodnih pojava, idiomi sa imenima artefakata (naročito kulinarskih jela) $\mathrm{i}$ idiomi sa nazivima delova tela.

Treći i poslednji varijetet intertekstualnosti je element korisničkog interfejsa, odnosno nazivi ciljeva (koji se takođe nazivaju i misije ili potrage) koje igrač ispunjava kako bi napredovao u daljem zapletu igre. Kratki i ekspresivni, ovi naslovi su formulisani tako da budu upečatljivi i često su zasnovani na aluzijama na engleske poslovice, popularne filmove ili klasičnu literaturu. Bavimo se njima takođe koristeći kvantitativni metod kako bismo izdvojili najistaknutije izvore aluzija (poput Biblije ili dela Vilijama Šekspira).

Ključne reči: intertekst, popularna kultura, video-igre, video igre sa igranjem uloga, frazeologija, engleski jezik

\section{REFERENCES}

Arnol'd, I.V. (1999). Интертекстуальность - поэтика чужого слова [Intertextuality — the Poetics of Another's Word]. Семантика. Стилистика. Интертекстуальность [Semantics. Stylistics. Intertextuality]. St. Petersburg: St. Petersburg State University, 350-363. (in Russian, Cyrillic script)

Bondar', М.P. (2006). Текст и интертекст [Text and Intertext] Личность-словосоциум 2006 [Person, Word, Society], 153-156. (in Russian, Cyrillic script)

Coolidge, F.-Wynn T. (2011). The Rise of Homo Sapiens: The Evolution of Modern Thinking. Hoboken, New Jersey: John Wiley \& Sons.

Genette, G. (1998). Фигуры [Figures]. Volumes 1 and 2. Moscow: Izd-vo im. Sabashnikovyh. (in Russian, Cyrillic script)

Hitchens, M.-Drachen, A. (2009). The Many Faces of Role-Playing Games. International Journal of Role-Playing, 1 (1), 3-21.

Konovalova, Yu.O. (2008). Языковая игра в современной русской разговорной речи: монография. [Wordplay in Modern Russian Colloquial Speech: A 
Monograph]. Vladivostok: Vladivostok State University of Economics and Service (in Russian, Cyrillic script)

Kornilov O.A. (2003). Языковье картины мира как производные национальных менталитетов. [Linguistic Worldviews as Products of National Mentalities] Moscow: CHeRo (in Russian, Cyrillic script)

Kristeva, J. (2000). Бахтин, слово, диалог и роман [Bakhtin, Word, Dialog and Novel]. Французская семиотика: от структурализма $к$ постструктурализму [French Semiotics: From Structuralism to PostStructuralism]. Moscow: Progress, 427-457 (in Russian, Cyrillic script)

Lakoff, G.-Johnson, M. (2003). Metaphors We Live By. London: The University of Chicago Press.

Lapshina, M.N. (2011). Интертекстуальность и устный перевод [Intertextuality and Interpreting]. Университетское переводоведение. Выпуск 11. Материаль XI международной научной конференции по переводоведению «Фёдоровские чтения» [University Translation Studies. Issue 11. Proceedings of the $11^{\text {th }}$ International Conference on Translation Studies "Fedorov Readings"]. St. Petersburg: St. Petersburg State University, 295-301 (in Russian, Cyrillic script).

Monsefi, R. (2016). Wordplay in English Online News Headlines. Advances in Language and Literary Studies. Australia: Australian International Academic Centre, 68-75.

Shestakov, V. P. (1988). Мифология XX века: критика теории и практики буржуазной «массовой культурыл» [The Mythology of the $20^{\text {th }}$ Century: a Critique of the Theory and Practice of the Bourgeoise "Mass Culture"] Moscow: Iskusstvo, 1988 (in Russian, Cyrillic script).

van Dijk, T. (1988). News as Discourse. Hillsdale, New Jersey: Lawrence Erlbaum Associates Publishers.

Vasil'eva, E.A. (2011). Функцииональная специцфика аллюзивных текстов (на материале пьес Т. Стоппарда «Розенкранц и Гильденстерн мертвы» $и$ «Tравести») [The Functional Features of Allusive Texts (Based on T. Stoppard's Plays Rosencrantz and Guildenstern Are Dead and Travesties): $\mathrm{PhD}$ Thesis]. St. Petersburg: St. Petersburg State University (in Russian, Cyrillic script). 